\title{
Secular, Islamic or Muslim feminism? The Place of Religion in Women's Perspectives on Equality in Islam
}

\section{Zora Hesová}

\begin{abstract}
The Western focus on 'Islamic feminism' takes two extreme forms: it is often dismissed as an oxymoron for attaching a religious (patriarchal) adjective to an emancipatory feminist project, or it is hailed as a road to a liberal, reformed Islam. Many Muslim feminists refuse to use this term; some reject feminism outright. There is consequently a tension within the term that many Muslim women activists acknowledge. In order to gain a better understanding of how religious and secular discourses combine in 'feminism in Islam', this text aims to examine the place of religion in women's emancipatory strategies.

When we look at the history, strategies, discourses, and especially at the concept of 'religion' Muslim women activists and thinkers deal with, a complex landscape emerges. 'Islam' ceases to be a reference to a given religious paradigm but becomes itself a contested terrain, one with religious, but also political, legal, and institutional actors. Theological, hermeneutical, post-foundationalist, reformist, legal, and social activism all envisage 'Islam' from different perspectives and locate the discriminatory aspects they resist in different fields of the Islamic paradigm or practice. The aim is to explore the meaning and practice of 'feminism in Islam' while taking a critical approach to an essentialist understanding of both Islam and Islamic feminism.
\end{abstract}

Keywords: Islamic feminism, Islam, secular feminism, secularity

Hesová, Zora. 2019. 'Secular, Islamic or Muslim feminism? The Place of Religion in Women's Perspectives on Equality in Islam.' Gender a výzkum / Gender and Research, Vol. 20, No. 2: 26-46, http://dx.doi.org/10.13060/25706578.2019.20.2.482.

While gender equality has been a persistent demand in Muslim societies for more than a century, and while feminist activism was at the forefront of many recent social movements in Muslim societies, the notion of 'Islamic feminism' remains veiled in a series of questions and doubts. Not only sceptical Westerners but also Islamists and 
some women activists in Muslim countries themselves question the accurateness and legitimacy of the term.

'Islamic feminism' may indeed appear as an 'uneasy' notion. First, the focus on Islam immediately raises questions about feminism's relation to religious authorities, references, and traditions that are often used to normalise, justify, or sacralise gender inequalities. It is sometimes dismissed as an oxymoron from Islamist and secularist perspectives. Both presuppose that a conservative (patriarchal) religion cannot be a part of liberal and emancipatory projects. At the other extreme, 'Islamic feminism' is readily hailed as an example and proof of the possibility of a liberal, reformed Islam - thus reaffirming the stereotype of Islam as a discriminatory religion. Hence the tension that exists within the term 'Islamic feminism'.

The uneasiness with Islamic feminism may have to do with the concept of religion. Yet what role does 'religion' really play in the construction of a feminist perspective in Islam? Must feminism be a project antagonistic to religion or can an emancipatory project stem from Islam? Are secular and Islamic feminism opposing or complementary projects? What 'religion' is really at stake? Religion as faith, or religion as a legal code and social institution? Religious dogma, theology, tradition, or the Islamic legal system?

The aim of this article is to look at 'Islamic feminism' from the perspective of a student of religion in modernity and to explore the place of 'religion' in Islamic feminism. The article will argue that the uneasiness about 'Islamic feminism' and the seemingly paradoxical nature of the concept are a product of a false dichotomy between the religious and the secular. This may indeed seem banal. Still, the difference between the religious and the secular is a persistent social and intellectual reality that theorists and activists have struggled with, and it cannot be simply dismissed. This purported dichotomy is never firm: Islamic feminism is indeed a field in which secular and religious elements constantly interact. A focused look at Muslim feminist writings and strategies will allow a complex picture to be painted of the religious emancipatory strategies that work variously with secular and religious elements.

After explaining the uneasiness surrounding the term Islamic feminism in the first part, the second part will elaborate the differences and also the mutual borrowings from and dependencies between the secular and the religious dimensions of Islamic feminism. The third chapter will then examine Islamic feminism's various types of religious reference by distinguishing between theological, legal, and social reformist strategies.

\section{Locating the Question}

At first glance, 'Islamic feminism' is an attractive but 'uneasy' notion, in the words of Margot Badran (Badran 2005: 15), a prominent historian of Islamic feminism. The term carries many connotations. Islamic feminism locates women's search for equality 
within a religious tradition but is also used as an example of a 'reformed' Islam. Because of the expectations that feminism will lead to a liberal Islam, some feminists reject being labelled as such. Asma Barlas), a Pakistani-born American Islamic scholar who without any doubt partakes in feminist discourse, has refused to call herself so: 'Calling myself a feminist was never a choice I was given. And, as I said, perhaps it was the combination of a perverse post-colonial sensibility and personal stubbornness that kept me from giving away my right to even name myself.' (Barlas 2006: 20)

Claiming a public identity as a 'feminist' may indeed be problematic in relation both to the West and to Muslim societies. First, women thinkers like Asma Barlas want to resist using Western terms such as feminism in order to avoid a Western appropriation of their work. Barlas perceives Western discursive encroachment as violent because the term is a vehicle of colonial projection: Any liberation is expected to come from the West towards the unfree East. 'To the extent that feminism in any form is complicit with this violence - which I believe it is when it reads oppression into Islam and reads liberation out of the West's imperialist depredations - I feel the need to resist it in all its forms.' (Barlas 2006: 20) Insofar as women's liberation is perceived as primarily of Western origin, the term 'Islamic feminism' may indeed carry stereotypes, that is to say, it may 'read oppression into Islam'. In their attempts to develop an egalitarian, non-discriminatory interpretation of Islam, Muslim women activists work to reject this oppression thesis.

Secondly, feminism's perceived Western origin weakens Muslim women activists' legitimacy in their own societies, by linking them to foreign, colonial projects. Such a perception is widespread among nationalists and fundamentalists; both fear that women's emancipation would lead to moral depravation and a loss of social identity. In this logic, the Moroccan women's mobilisation of the early 2000s was perceived by the Islamists as a West-inspired, secularist, individualist, and Westernising project (Salime 2011: 24)

Further, contemporary women activists reject the public identity of Islamic feminism for very different reasons too. In her research on Lebanese women activists and thinkers, A.-K. Steger has encountered only one interlocutor who would accept the term. Another chose to call herself a 'Muslim theologian' for being primarily focused on theological issues and not on feminism. Yet others called themselves feminists but rejected the adjective 'Islamic' because religion was not their only inspiration. Yet others refused the term 'feminism' as it would mean that they were seeking only the betterment of women and not social improvement for everyone (Steger 2017). The acceptance of the term may also be low because of its perceived secularist character. Asma Barlas explains that 'for the most part, feminism has secularized the idea of liberation itself such that feminists often assume that to be a believer is already to be bound by the chains of a false consciousness that precludes liberation' 
(Barlas 2015: 164). Thus, the sole focus on women's issues seemed too narrow for a theologian, and an insistence on religion seemed restrictive to secular thinkers. Still, in the Lebanese case, all interlocutors accepted the strategic need to address women's issues within a religious context and many did use the term Muslim feminist (Steger 2017: 18-19).

'Feminism' is thus a term that is tainted with unwanted connotations: Western appropriation, non-religiousness, a narrow focus on women's issues. For others the adjective Islamic is the problem. Yet 'Islamic feminism' remains a widely used term, rather than, say, 'Muslim feminism', 'Qur'anic feminism' or 'feminist hermeneutics'. Islamic feminism seems to be 'a catch-all term' that is used in reference to different actors, even to those who may not accept it (Rhouni 2010: 22)

If the term itself is very general, it does represent a connexion between an egalitarian project and religion. Even such a general term still raises questions: Is the feminist interpretation of Islam - or Islamic feminism - something altogether different from secular feminisms in Muslim countries? Islamic feminism seems to combine two different sets of discourses: religious legitimation or a religious mandate (implying a normative heteronomy), and secular rights (implying personal autonomy). Rather than postulating a dichotomy between the two, the aim of this analysis is to explore the various positionings of religion (Islam) in various types of feminism. A first distinction that needs to be explored is Islamic and secular feminism; afterwards, we can ask if there is a difference between Islamic and Muslim feminism.

\section{Secular or Islamic Feminism?}

According to Margot Badran, the first feminism to develop in Egypt since the early 20th century was secular feminism, and an 'Islamic' feminism emerged as a phenomenon identified as such only at the end of 20th century (Badran 2009). The secular/religious distinction is crucial because it helps to locate 'Islamic feminism' within the broader and older sphere of the secular feminist movement. Here, secular and Islamic are not necessarily in opposition to each other: Badran's distinction between secular and Islamic feminisms rests on the strategies that women activists use, rather than on their intellectual references. Secular feminism seeks to achieve civic equality (e.g. in politics/the political sphere, labour rights, and education) and Islamic feminism works towards an egalitarian theology.

\section{Secular feminism}

The first feminist positions that developed in Egypt were secular in the sense that they were formulated within the frame of a (nascent) national state and in terms of equal rights for men and women in the public sphere. Secular feminism was part of 
a modernisation effort that aimed to bring civic and political rights to colonial subjects with the intention of including women in the modernisation process. Women were fighting for the right to get an education, to work, to vote, to be active in the public space, and generally for the right to personal self-determination.

In the beginning, feminist positions in Egypt were conceived independently of any religious affiliation and feminist groups included Coptic women. This is not to say that they were all secularist in the sense of conceiving of a public sphere without the influence of religious authorities or even of being militantly hostile to religion. On the contrary, the first generation of secular feminists made use of a broad range of humanist, secular-nationalist, and Islamic-modernist discourses. Most crucial among the concerns of Muslim secular feminists was the reform of Muslim family law. The first generation of Egyptian feminists drew upon a modernist Islamic discourse to seek reform of the patriarchal family and argued for a more egalitarian status law, focusing especially on the abuse of unilateral divorce and polygamy (see Badran 2009: 55-64). They were inspired by reformist figures such as Mohamed Abduh and Qasim Amin and their efforts to reform Islamic law and practice in light of the requirements of modern times (Badran 2009).

The same mobilisation to reform the civil code motivated Moroccan secular feminists (Salime 211: 23). In most countries, including those most advanced in women's issues, feminist demands continue to be articulated in terms of social and civic rights and buttressed by a varying mixture of humanist, secular, and Islamic arguments. Rightsbased feminism did not stop developing in Muslim in modern national states after decolonisation. Independent states did fulfil feminist demands to a certain degree, often formally (giving women vote and right to education), while curtailing others (as we shall see later).

\section{Islamic feminism}

Islamic feminism has a different take on women's emancipation. In the widely accepted definition by Margot Badran, Islamic feminism is 'a feminist discourse and practice articulated within an Islamic paradigm. Islamic feminism derives its understanding and mandate from the Qur'an, seeks rights and justice for women, and for men, in the totality of their existence' (Badran 2009: 242). It differs in several respects from 'secular' feminism: While secular feminism constituted a social movement accompanied by academic feminist texts, Islamic feminism in the beginning was rather an intellectual endeavour. It was a new, modernist discourse seeking to ground gender equality in the very source of the religion, the Qur'an.

According to Margot Badran and other writers, Islamic feminism started to emerge in the 1990s or was only then identified as such by Western academia. The contributors to the Teheran women's magazine Zanan developed a self-understanding of being 
Islamic woman activists between 1992 and 2008 (Mir-Hosseini 2006: 640-641). The term was also used in reference to the veiled Turkish Islamic activists who were consciously resisting their secondary social roles in the industrialising, secularist Turkey of the 1990s (Göle 1996: 121-125).

Looking back at the emergence of Islamic feminist thought, M. Badran has reconstructed a history of religion-inspired feminism to show that the female religious voice has been present all along since the early 20th century (Badran 2009: 313). Yet as a distinct and influential phenomenon, it really appeared in the late 20th century in a specific context. While the modern national state was the context in which secular and rights-based feminism first developed, rising Islamism was the context in which Islamic feminism emerged. It was caused by a resurgence of patriarchal and conservative thought in political Islam - whether in the Iranian theocracy, where the authoritative state came to control women's issues, or within socially conservative Islamist movements elsewhere. Women living in such newly explicit patriarchal contexts sought to formulate their positions no more in terms of civic rights, but in a religious language. They were the new 'religious women' (al-mutadayyinat) - like, for example, the Egyptian Islamist activist Zeinab al-Ghazali, and the Iranian reformists grouped around the aforementioned Iranian magazine Zanan (Women).

In the 1990s a series of books were published on the issue of women in Islam from a feminist perspective that sought to ground women's liberation from oppressive norms in the very source of the religion, the Qur'an. First, it was the Moroccan sociologist and academic Fatima Mernissi's reconstruction of the patriarchal bias in the hadith science throughout Islamic history (Mernissi 1991a). Then, the North American Islamic scholar Amina Wadud published an original feminist view on Qur'an and Woman: Reading the Sacred Text from a Woman's Perspective (1999) with the aim of showing that the Qur'an contained a message of gender equality and justice. Her work was carried to a deeper level in 2002 by the Pakistani-American scholar Asma Barlas in the book 'Believing Women' in Islam: Un-reading Patriarchal Interpretations of the Qur'an.

Since then, many Muslim activists have been inspired by the foundational work of Islamic feminists to develop their own feminist thought in various contexts. The Bosnian Islamic scholar and activist Zilka Spahić-Šiljak attests to the importance of the perspective of gender justice within religion that was introduced by the abovementioned writers. She and her activist colleagues found confirmation and inspiration while working in post-war healing and reconstruction from a religious women's perspective (Spahić-Šiljak 2017). 


\section{The radicality of religious feminism}

Yet, Muslim women writers and activists are not always open to the term feminism. Asma Barlas, whose reservations were quoted above, only came to accept Margot Badran's definition cited above because it avoided the inner tension usually invested in this term by locating feminism within religion. The reason is that 'Badran offers something tempting by de-secularizing the project of women's liberation. As she makes clear, it is not only Westernized secular humanism but, also a specific mode of God-consciousness that can lead us to emphasize justice and rights for all human beings by affirming the unity and equality of human life' (Barlas 2008: 20). The anchoring of religious feminism in a 'specific mode of God-consciousness' marks a different kind of approach. And, according to Margot Badran, it is in some ways more radical.

While secular feminism was decidedly socially reformist, it concentrated on the public sphere and on the struggle for related rights and failed to conceptualise equality in the private sphere. It left the religious aspect and the private aspect of social life unattended, accepting unequal rules and religiously defined gender complementarity within religious institutions and in family relations, respectively. Islamic feminism on the other hand extended the demand of equality to those spheres, too. Some feminists questioned male dominance of Islamic functions and demanded access to the positions of judge and mufti. Arguing for the Islamic permissibility of female magistrates, they have partly succeeded in some Muslim states. In seeking equality in the private life, religious feminists had to develop arguments that went beyond early Islamic modernist thinking. Asymmetrical gender roles, with men possessing all the power, were rooted in a conception of gender complementarity regulated by shari'a rules and religious habits (Badran 2010: iv-v).

Religious feminists set out to question the foundational texts of religion and to reconstruct the history of female subjugation in the Islamic legal tradition. In doing so, Islamic feminist brought down the disconnection between the public and private sphere and conceived of a more radical human equality that transcends tribe, class, race, and gender (Badran 2008: 33). The private sphere indeed proved much more resistant to modernisation than public rules about access to education or political rights. Discriminatory rules and beliefs have not vanished with the emergence of modern states and republics, but they were most often (except possibly for Turkey and Communist bloc Muslim countries) integrated into the modern state's personal status laws. Precisely because of their religious and cultural grounding they proved difficult to reform even in modern secular states. Marriage, inheritance, divorce, custody, and so forth, remained the last legal sphere under the authority of religious principles.

The fact that many modern family laws in Muslim countries contain and implement principles of gender hierarchy and complementarity has prompted an Islamic 
feminist response. In post-revolutionary Iran, shari'a principles became codified into conservative, discriminatory state laws, while, on the other hand, women were being pulled into social and religious activity by the same regime. This paradoxical situation led feminist activists to challenge the Islamic foundation of what they perceived as discrimination (Mir-Hosseini 2006). The prominent feminist thinker and legal anthropologist Ziba Mir-Hosseini recounts that she came

to confront these questions in 1979, when a popular revolution in my country, Iran, transformed my personal and intellectual life. Like most Iranian women, I strongly supported the 1978-79 revolution and believed in the justice of Islam; but when the Islamists strengthened their hold on power and made the shari'a (or their interpretation of it) the law of the land, I found myself a second-class citizen. This brought the realization that there can be no justice for me, as a Muslim woman, as long as patriarchy is justified and upheld in the name of Islam. The prevailing interpretations of the shari'a do not reflect the values and principles that I hold to be at the core of my faith (Mir-Hosseini 2006: 629).

From the end of the 1980s onwards, Iranian thinkers have embraced methodologies developed in the new religious thought in Iran to innovatively debate the Islamic foundations of the legal and social order.

\section{Complementarity and cooperation}

Margot Bradan's conceptualisation described above defines rights-based feminist activism as secular and theological feminist reasoning as Islamic. This distinction is not meant as a dichotomy, but as a tool intended to describe the historical development of various feminist discursive strategies. Secular does not mean 'secularist', and Islamic does not mean anti-modern. Secular and Islamic feminisms have indeed been complementary of each other, and they have increasingly inhabited shared spaces.

Seeking an extension of the agency of educated women in the public space, secular modernist feminists were not necessarily radically secularist - nor were they consistently radically emancipatory. Once modern independent republics were founded, secular feminism was integrated into a kind of state feminism. In Kemalist Turkey and in post-independence Egypt certain feminists were made part of statesponsored and state-controlled women's advisory bodies that had to accommodate a series of discriminatory provisions and practices cloaked in a secular language. State feminism represented a kind of deal - some activists accepted the limitation of their autonomy within a nominally secular state in exchange for entrusting the state with implementing social reforms (such as a banning and a campaign against female genital mutilation in Egypt). Yet state-feminism has also all too often led to 
their co-optation and a loss of legitimacy (Abou-Bakr 2015) - with notable exceptions of course. ${ }^{1}$

Secular feminists are often engaged in campaigns related to religious stipulations and political forces. If advancing religious equality means questioning legal provisions based on religious arguments, it also means confronting the institutions that rule on the basis of shari'a principles. In modern Muslim societies, these principles are mostly incorporated into state family laws and personal codes. Therefore, the state exercises the power to interpret the religious law. Under the influence of humanist thinking, international law, and religious arguments, modern Arab states have, for example, put hudud sentences on hold, banned polygamy (Tunisia), or reformed older personal status laws in direction of a more egalitarian law. The most notable change was the reformed Moudawana code in Morocco, adopted in 2004, which stipulates legal equality between the sexes. Moroccan activists keep pushing for an even more egalitarian state law: for the abolition of inheritance inequality a shari'a provision - that persists in the Maroccan personal status code. In March 2018, prominent intellectuals, including the feminist writer Leila Slimani, but also the prominent Moroccan Islamic feminist and physician Asma Lamrabet, have signed a petition for inheritance equality. Lamrabet has argued for full equality based on Qur'anic principles in several books before. Yet, after some states have embarked on a more liberal course, the conflict concerning women's rights has moved onto a religious field, into a standoff between conservative Islamic authorities and Islamist parties on the one hand, and liberal or reformist Islamic and lay activists on the other. Asma Lamrabet was eventually forced to resign from a state position under pressure from conservatives. ${ }^{2}$

Because of the conflation of legal and Islamic argumentation, the need for cooperation between secular and religious approaches has increased. For two dozen years, indeed, secular activists have been reflecting on the results of Islamic feminist thought and Islamic activists have adopted secular strategies to challenge state laws and to seek reform through public activism. Resistance to discriminatory family law codes was also the main motivation for early projects of sharing experiences and strategies in first transnational Muslim feminist networks such as Women Living under Muslim Laws (WLUML) founded by Maghrebi, African, Central and South Asian, and French feminists in 1984. It has since extended to include 70 countries across the globe - to Muslim majority countries, but also to secular states with religiously inspired

1 One was the Egyptian feminist Nawal al-Saadawi, who first worked for the Egyptian Ministry of Health before falling out over her criticism of female genital mutilation and being imprisoned and forced to leave the country.

2 'Feminist Asma Lamrabet under Pressure', Qantara.de, accessed on 5 April 2019: https://en.qantara. de/content/islamic-inheritance-law-in-morocco-and-tunisia-feminist-asma-lamrabet-under-pressure. 
family laws or Muslim minorities who perpetuate conservative social principles. In 2006 WLUML published a compendium titled Knowing Our Rights: Women. Family, Laws and Customs in the Muslim World, ${ }^{3}$ showing the disparities, local variations, and foreign influences in family law applications in the Muslim world. The compendium helped demystify the idea of a unique and immutable Islamic law.

Another group, founded in the late 1980s, called the Sisterhood Is Global Institute (SIGI) published a religiously inspired handbook in 1996 focusing on the way women rights are anchored in the Qur'an and hadith. Claiming Our Rights: A Manual for Women's Human Rights and Education in Muslim Societies was translated into a dozen languages and was used by various activist NGOs across the Muslim world as the basis for extensive human rights educational and empowerment programmes (Moghadam 2009: 158). Here, religious reasoning was recognised as a practical and indispensable tool for emancipation and legal reform.

Other groups, such as the Indonesian Muslim organisation and the transnational network WISE (Women's Islamic Initiative in Spirituality and Equality, founded in Malaysia in 2010) include Muslim Islamic and Muslim secular feminists and have religious and secular members. The WISE network seeks a religious influence, if not informal religious authority, through its 'shura' (advisory council), which formulates statements on women's issues in Muslim countries. Although WISE is primarily active in the religious field (also, for example, by providing trainings for imams on gender issues), self-identification as Islamic and feminist occurred after a period of questioning about the use of language. Would the ' $E$ ' in WISE mean outright 'equality' or the more accommodating and vague notion of 'Equity'? The WISE network eventually opted for Equality, that is, it chose a secular framework for its (most often) religious activism (Badran 2010: xix).

In sum, it is possible to identify various feminist strategies (social reformist, egalitarian, religious, theological), but it has become hard to construct opposites between the two types of feminism. Islamic feminists engage also in secular struggles while secular activists promote a consciousness of the diversity of Islamic law and its interpretations. Examples of cooperation abound: Turkey's secular feminists have supported the right for women to veil in state facilities; in Yemen, Islamist and secular activists have supported the political participation of women; in Morocco, secular and Islamist women feminists have ended up directly influencing each other (Salime 2011).

\section{Mutual dependence}

While women's Islamic strategy towards emancipation needs to be recognised as original, it is hard to imagine that it could have developed without a series of secular imports and conceptual tools, that is, outside the context of feminist critique,

3 Available at the WLUML page: http://www.wluml.org/node/588. 
discourse, and consciousness. Even primarily religious arguments are based on nonreligious methodologies and conceptual tools. The perspectives of modern social theory - above all the constructedness of gender, the historicity of traditions, and the discursivity of power - seem as crucial for the development of the Islamic feminist perspective as they are in Western feminist thought.

Feminist vocabulary and a corresponding perspective are the central arguments of the founding texts of modern Islamic feminism. The concepts 'misogyny' (Mernissi 1991), 'patriarchy' (Wadud 1999), and 'gender' (Wadud 2006), the differentiation between biological sex and socially constructed gender roles, the concepts of gendered language, gender bias, gender politics, gender justice, and gender parity are all fundamental to the critical perspective of Islamic feminists; so are the modern interpretative disciplines and methods - such as hermeneutics, intertextuality, historicity - to which Islamic feminists themselves refer.

Amina Wadud introduced 'gender' as the absent 'principle category of thought and as an aspect of analysis in the articulation of Islamic ideals' (Wadud 1999: xi). She based her Qur'anic interpretation on a gender perspective in her research that would result in Qur'an and Woman: Rereading the Sacred Text from a Woman's Perspective (1999). She went on to write a book on Islamic feminism called 'Inside Gender Jihad: Women's reform in Islam' in 2006 - avoiding 'feminism' but confirming the importance of the notion of 'gender'. Since then, 'gender' has come to be widely used as an analytical category by religious scholars and theologians who seek to offer an alternative understanding of the religious tradition and a critique of its patriarchal construction.

Asma Barlas sought to unread 'patriarchal' interpretations of the Qur'an. In Believing Women in Islam, she developed two definitions of patriarchy: patriarchy as a tradition of father-rule, and as a politics of gender inequality based in theories of sexual differentiation in the patriarchal religious hermeneutics (Barlas 2002: 2). In The Veil and the Male Elite (1991), the Moroccan pioneer feminist Fatima Mernissi showed how a 'misogynous' law had developed out of the selective ue of certain weak hadiths.

A gender perspective has entered even Islamist activist circles. Raja Rhouni cites a critical statement made by Nadia Yassine, a prominent Islamist activist and the daughter of a leading Moroccan Islamist leader, in an interview for Oumma in 2003, where she said that 'La jurisprudence musulmane est machiste' (Muslim jurisprudence is macho) (Rhouni 2010: 23). Obviously, she would not say that she is an Islamic feminist: she led the Islamist demonstration against the secular feminists' campaign for the reform of the civil code in Morocco and took a stance against 'feminism' (Salime 2011:19). But critical terms and ideas have permeated the Islamist realm too, as Zakia Salime shows by quoting Nadia Yassine saying: 'For years, I kept repeating that women did not have problems with Islam. Now I am saying: we do have problems; I mean with the way Muslim men stole this religion from us' (Salime 2011: 19). 
This is not to say that feminism in Islam originated as a Western import. But Western social science provided some of the tools for women's theological critique, as noted by Fatima Mernissi: 'Our liberation will come through a rereading of our past and a re-appropriation of all that has structured our civilization.' (cited in Rhouni 2010: 22) Asma Barlas, in a personal note, confirms the role of Western feminist theory as one source of the instruments applied to specifically Muslim issues:

My resistance to feminism stems not from its central premise that women and men are equally human and deserving of equal rights, but from two facts: First, I dispute the master narrative of feminism that claims this insight as a peculiarly feminist discovery. In my own case, for instance, I came to the realization that women and men are equal as a result not of reading feminist texts, but of reading the Qur'an. In fact, it wasn't until much later in my life that I even encountered feminist texts. But I do owe an intellectual debt to feminist theorizing about patriarchy and for having given me the conceptual tools to recognize it and talk about it. (Barlas 2015: 164)

'Secular' and 'Islamic' feminisms are thus imperfect descriptions for a variety of women's emancipatory positions in Muslim contexts. While denoting two separate strategies, they feed on shared instruments and have increasingly entered into a relationship of cooperation and complementarity. In the words of Margot Badran: 'Secular feminism and Islamic feminism appear to be increasingly blending: thanks to the above mentioned cooperation but also due to a sort of "continuum" there is between religious inspired and secular informed feminism.' (Badran 2010: xix). Thus her preferred choice of words was feminism in Islam.

\section{Islamic Feminism, Muslim Activism, Feminist History}

Even as secular Muslim feminism and Islamic feminism increasingly converge in their actions and complement each other in their types of discourse, they must differ in their understanding of religion and women's issues. Otherwise there would be no reason to use those adjectives. Yet, what kind of relations do different types of feminisms entertain with religion and what does religion mean for them?

According to Badran's widely accepted definition, Islamic feminism is a 'feminist discourse and practice articulated within an Islamic paradigm. Islamic feminism derives its understanding and mandate from the Qur'an, seeks rights and justice for women, and for men, in the totality of their existence' (Badran 2009: 242). ${ }^{4}$ Notably, Badran

4 Also available at the website of al-Ahram, where it first appeared. Accessed on 5 April 2019. http:// weekly.ahram.org.eg/Archive/2002/569/cu1.htm. 
does not speak of religion, but of the Qur'an and of the 'Islamic paradigm', that is, she refers to the revealed source of Islam and to the religious matrix through which Qur'anic principles come to life in a historical process. It is precisely the distinction between foundation and reception, between religion and religious thought, and between religious tradition and modernity that allow Muslim feminist thinkers to open space for contestation and reform.

Consequently, when speaking of 'religion' in Islamic feminism, we refer to a general 'Islamic paradigm'. There are three principal ways to critically approach the 'Islamic paradigm': through critical theology and ijtihad, through critical religious thought, or through critical readings of legal history.

\section{Islamic feminism as theological discourse}

The best known and most influential works of Islamic feminism are projects of a 'theology-driven feminist discourse' (Badran 2010: 2) that engage in a radical interpretation of the revealed sources and of the religious tradition itself. While all founding Islamic feminist thinkers were 'lay' thinkers, that is, women (and fellow male reformist thinkers) primarily educated outside of traditional centres of learning, they sought to reconnect with the Islamic tradition. They engaged in a specific approach to religious sources and to tradition: i.e. in attempts at 'rereading' and 're-appropriation'. Through traditionally sanctioned methods of interpretation they sought legitimacy in the eyes of believers and the authorities.

One of them is ijtihad, a personal effort to rationally deduce principles from the Qur'an (as opposed to a reasoning based on analogies or collective deliberation). It was commonly accepted that ijtihad as a practice was largely abandoned in the Sunni Islamic tradition after the corpus of Islamic law was put together in the Middle Ages. Especially from the 18th century on it was deemed that it was increasingly difficult to infer authoritative norms from a revelation whose occurrence was retreating into the distant past. Consequently, the number of 'mujtahids' who engaged in rational inquiry declined (although the practice never fully disappeared; see Hallaq 1984). Yet, since Islamic law came to be codified in the modern state's Personal Status laws, every reform to it has needed some degree of ijtihad (Mir Hosseini 2007). Since the beginnings of Islamic reformism and its revival in the 1990s, modern religious thinkers have taken to ijtihad again and developed independent, personal, rational, and critical approaches to Islamic theology, Islamic history, and the whole Islamic 'legacy' based on an array of critical Muslim and non-Muslim sources. ${ }^{5}$

5 Barlas (2002) refers to critical thinkers such as E. Said, T. Asad, F. Rahman, A. an-Naimand M. Arkoun; A. Wadud (1999) refers to F. Rahman, A. Qasim and post-positivist philosophers John Austin and John Searle; Mir-Hosseni (2006) refers to A. Soroush and others. 
Islamic feminism revived the practice of ijtihad to engage in feminist or gendersensitive tafsir, the Qur'anic interpretation or exegesis of revealed text (Hidayatullah 2014). By resorting to modern hermeneutic exegesis, they challenged the received interpretations of the part of the Qur'an that relates to male-female relations. Resituating the letter of the Qur'an into its historical, literary, and linguistic context, they showed how its reception was historically constructed: usually drawing upon a selection of prophetic traditions, hadiths, a traditional interpretation that emphasised the patriarchal meaning of the text (Mir-Hosseini 2013). By proving the historical contingency of such a traditional patriarchal reading, Islamic feminists made a case for a reformed, egalitarian Islam.

For Amina Wadud, the hermeneutical model allowed for different readings depending on the chosen emphasis between the grammatical and the literal, the contextual and the ideational aspect of the text (the world-view contained in the text, Wadud 1999:3). Fatima Mernissi used 'an original and contextualizing methodology to approach gender in Islam, which foregrounds the historicity of Islamic texts and the contingency of some gender norms' (Rhouni 2010: 12). In doing so, Islamic feminists 'challenged oppressive readings of the Qur'ān' and also 'offered a reading that confirms that Muslim women can struggle for equality from within the framework of the Qur'ān's teachings, contrary to what both conservative and progressive Muslims believe' (Barlas 2002: xi).

These re-interpretation efforts have been criticised for apologetic tendencies as well as for what Rhouni refers to as 'foundationalism' in their relation to religion. In her view, Islamic feminism of Mernissi and Wadud is focused on a rereading of the Qur'anic message with the aim to 'retrieve gender equality as a norm established by the Qur'an' and to retrieve 'an egalitarian Islam' from it (Rhouni 2010: 253, 254). Yet this amounts to seeking a true and solid foundation in the text that is conceived as a 'repository of truth' (Rhouni 2010: 272). Explaining away its problematic passages through egalitarian hermeneutics testifies to 'a tendency to remain captive to the very (patriarchal) scholarly tradition they wish to disrupt' (Badran 2010). Rhouni calls for a 'post-foundationalist islamic gender critique [lower case intended]' (Rhouni 2010:37). A radical ijtihadi approach would deconstruct the habitual interpretation strategies, strengthen the contextual approach to the text and go 'beyond the dogma of Islamic feminism that gender equality is foundational to the Qur'an' (Rhouni 2010: 272).

While the Islamic feminist efforts were intended to show that the message of the Qur'an was egalitarian, post-foundationalist interpreters would not content themselves with proving that the religious foundation guarantees full equality of all human beings; they would rather seek to re-interpret the concept of revelation, to review the 'androcentrism' of the Qur'an, and generally to rethink the status of the revealed text. Such radical ijtihadic endeavours would not necessarily be feminist 
anymore. An example of such a post-foundationalist approach is Jacqueline Chabbi's radical historical-anthropological reading of the Qur'an (Chabbi 2016). She attempts to replace the revelation in the context of orality, tribal relations, and related 'modalities of faith' and to show how 'men (people) make texts speak' (Chabbi 2016: 9). Without writing 'the three pillars of Islam' with a feminist or egalitarian intention, her antifoundationalist approach may be one of the many crucial contributions to a more humanist understanding of the revelation's message.

\section{Religious resistance to patriarchal norms}

Besides feminist theology there is also a feminist Islamic practice of lay people, publicists, and activists who are trying to formulate practical women's concerns in a religiously legitimate language. An example is post-war peace activism on Bosnia. A feminist religious practice became a necessity for believing women when they needed to make sense of an unjust or unprecedented situation and find religious responses to it. Zilka Spahić-Siljak recounts that after the 1992-1996 war in Bosnia-Herzegovina, Islamic feminist practice emerged among women engaged in psychological assistance and reconstruction. There were questions and needs that the existing religious authorities were unable to respond to, so women took the initiative to find women-centred Islamic solutions themselves - for example, by assisting victims of trauma: 'We applied ijtihad or independent reasoning to comfort human beings who experienced terrible pain just because they belonged to a particular ethnic and religious group.' (SpahićŠiljak 2017: 170) Later, once Western, secular and Islamic feminist literature became available, Spahić-Šiljak made sense of this experience in light of various feminist theories.

Different feminisms do indeed respond to different situations. Thus, the 'secular' feminism of public rights emerged in the modernisation process that occurred at the beginning of the 20th century; Islamic feminism was paradoxically a reaction to policies of state-imposed Islamisation of legal norms (Mir-Hosseini 2007). As a retraditionalisation process was under way in the 1980s and 1990s, feminists had to engage with religion to bring about change and rethink the role of religion in the modern state and in modern ideologies. Hence, a disillusionment with politicised religion brought about a religious response.

The shari'a-based regime in Iran, according to Ziba Mir-Hosseini, has not led to progressive development for women. If anything, codifying shari'a meant the elevation of tribal laws and patriarchal habits into a religiously sanctioned rule - for example, by curtailing the right of women to consent to divorce. The Iranian theocratic republic has remained very much 'out of touch with modern society' and with evolving social realities such as women's aspirations and people's sense of justice (Mir Hosseini 2006: 634). A feeling of injustice led women to 'voice their discontent'. Ziba Mir-Hosseni 
recalls that during some of her visits to Iranian courts 'the Islamic judges in whose courts I sat in the 1980s often told me that I had chosen the wrong place to learn about the shari'a. I should go to the seminaries, they said, to read fiqh texts and discuss them with the ulama; the courts had nothing to teach me about the shari'a (Mir-Hosseini 2006: 635).

Intellectuals and publicists with a secular, reformist perspective (but also with a religious education and/or inclinations) entered the space of legal Islamic discourse with a critical view of law and jurisprudence - for example, in campaigning against stoning. They have engaged in a more substantial kind of reflection on the religious legitimacy of discriminatory social norms imposed in the name of the shari'a. Iranian feminism has developed a response in the framework of the so-called New Religious Thinking or religious intellectual reformism (Mir-Hosseini 2006: 636). In the view of its best-known representative, the philosopher of religion Abdolkarim Soroush, religious knowledge evolves, contracts, and expands, because it is a human product (Soroush 2008). In the reception of his thought by Iranian feminists, an important distinction was made: between shari'a and figh. The former stands for revealed divine will and guidance, while the latter for Islamic jurisprudence. In Soroush's view, only the first is immutable and absolute. Religious knowledge and applied Islamic law, on the other hand, are man-made, human perspectives on the revelation. So figh is the result of the human endeavour to deduce principles and legal rules from the revealed sources of religion. As such, it is neither immutable nor sacred; it is subject to change. Patriarchal norms are also a matter of figh, literally human discernment, and not of shari'a, that is, divine will. The distinction creates a space for reform, as the confusion between shari'a and fiqh needs to be undone; legal provisions concerning gender hierarchy and gender roles can be challenged without challenging religion itself.

Post-revolutionary Islamic feminism in Iran was thus employing a different strategy than intellectual Islamic feminism. It dealt with the Islamic paradigm by critically reflecting on religion, revelation, truth, and human religious knowledge. It made it possible to question retraditionalisation based on the confusion of patriarchal social norms with shari'a. Such a strategy can be extended to responding to Islamism: it has a tendency to sacralise fiqh into legal norms too. Islamists claim a shari'a mandate for themselves while sanctifying a discriminatory social order. Critical Islamic thinking aims, on the contrary, to de-sanctify and secularise figh (Mir-Hosseini 2006: 637), while preserving an absolute, politics-free status for revelation.

\section{Feminist scholars of legal history and practice}

The last example of a critical take on religion's role in legitimising the discriminatory social order comes from Islamic feminists who look at the interplay between religious legal norms and modernity. Religious rules are mostly 'exercised' in the sphere of the 
social enforcement of normative systems. This sphere of courts, judges, laws, and fatwas is opaque and complex. Its modes of functioning owe as much to religious principles and ideologies as to the institutions themselves.

Amira Sonbol, an Egyptian-born professor of Islamic history at Georgetown University, has reversed some of the received opinion on gender norms in the legal history of Egypt. She has shown that traditional fiqh had a great degree of flexibility with regard to female activity in the public sphere and female agency in general. Ottoman era court records in Egypt reveal women as being socially and economically active, present, and vocal in the courts, pursuing their rights and large numbers of women obtaining divorce (Sonbol 2002:113). According to Amira Sonbol, modernisation has led to a deterioration of women's position by codifying the largely horizontal and flexible legal practice of the former shari'a courts into rigid modern family codes. National codes have been constructed selectively: they have effectively picked and chosen provisions that cement men's control over women and thus closed the door on spaces that were previously open to be negotiated and formalised rigid and patriarchal systems (Sonbol 2002: 112-113).

In this view, the problem with 'religion' legitimising patriarchy has less to do with its foundational texts or even with shari'a or figh itself and more to do with the institutions that realise justice in the name of religion. Sonbol challenged the received view on the conservativeness of shari'a: looking at the legal practice, patriarchy may not be primarily a vestige of the past, but may equally be a product of modernity (Sonbol 2002:144).

Even before the recent trend towards re-traditionalisation among Islamic fundamentalists, modern states, sometimes even nominally secular states such as Egypt, have brought about a rigid, simple, and homogenising system of state application of the religious law. In doing so, secular forces - state legislatures - have engaged in a very non-traditional kind of figh. This understanding of the complex relations between religion, modern states, and social conservativism displaces the attention yet further away from 'religion' and even away from the Islamic law per se, towards the state institutions that apply fiqh.

The Moroccan scholar Souad Eddouada, demonstrated the even subtler role of state-organised jurisprudence in maintaining discriminatory practices. In her work on recent family code reforms in Morocco, she concurs with Amira Sonbol in seeing the traditional figh system as pluralistic to a certain degree and modern colonial states' bureaucracies as motivated by gaining control over populations through law. She analysed the persistent discriminatory jurisprudential practice even in a state whose laws have finally recognised a measure of gender equality (Edouada 2008: 39). When Morocco adopted the revised Family Code in 2004, the act was hailed as a unique sign of progress in the Muslim world and as a victory of the women's movement. Not 
only did it restrict polygamy and give women the right to divorce, it also recognised legal equality between men and women. Yet the actual implementation of equality falls far behind the state's purpose. S. Edoudada shows that jurisprudential practice is very often not egalitarian. She observed many 'exceptions' that were granted in recognition of local habits (for example, in matters of underage marriage) and documented cases of impeded access to divorce, alimony, and custody (Eddouada 2008: 43-44).

Not surprisingly, patriarchy is engrained in legal practice the code's advancement notwithstanding. Feminist efforts to create a movement and to advocate against discriminatory legal provisions is thus just one aspect of feminist action. Another is to empower women to be able to claim and obtain their rights. Consequently, in parallel to legal activism, women's groups in Morocco have established so called 'listening centres' to provide legal advice for individual cases of discrimination or misuse of the law (Eddouada 2008: 42). Besides discriminatory legal practices, socio-economic realities are in themselves a yet deeper root of discrimination. Social empowerment of the weak is (evidently) as important as legal empowerment.

S. Eddouada's conclusion echoes a similar reflection on women's activism in Iran. According to Fatemeh Sadeghi, the impressive intellectual feminist group around the journal Zanan (1992-2008) became weaker after 2008, but not only because of the conservative authorities' crackdown on the liberal 2009 movement. Sadeghi explains that the group had succeeded in making 'gender equality' and women's participation a political issue, especially in reformist Iranian circles. Yet, Islamic feminism came to be seen as elitist. Above all, it achieved little when it comes to the social situation of women struggling with high unemployment, inflation, a drug crisis, and marginalisation (Sadeghi 2010: 217).

In conclusion, the historians, social scientists, and activists mentioned above can hardly be called primarily Islamic feminists. Nevertheless, like the Islamic theologians, they are engaged in efforts to bring about a more egalitarian reality with respect to Islamic thought, national history, legal systems, court practices, and social life. Many of them are simply Muslim or are defined primarily by their profession. They are all engaged with some aspect of religion; yet only certain among them do so in a normative way. The term 'Islamic' seems more fitting for the theologians, who are primarily concerned with the message of Islam. Yet, the fact is that they all fall under the catch-all term of Islamic feminism, as Islam in its normative, legal, institutional, and discursive aspects continues to affect many fields of social reform. 


\section{Conclusion}

The term 'Islamic feminism' covers a large variety of approaches to gender equality in Muslim contexts. There may be no single paradigm with which it would be possible to capture the variety of theological, ijtihadi, intellectual, legal, and social discourses and activism strategies that exist. The functional differentiation between a 'secular' Muslim feminism and a 'religious' Islamic feminism seems to be analytically interesting and useful for historical purposes, but it hardly reflects a distinction in real terms. In feminist practice, Islamic and secular approaches overlap: Islamic feminist thinkers rely on social science concepts and social activists work with religious knowledge produced by Islamic feminists. Also, as a gendered perspective becomes widespread among hermeneutical and universalist theologians and thinkers, it may eventually become less important to stress the adjective 'feminist'.

If the term Islamic feminism seems contradictory in the abstract, a closer look at the various Muslim feminist trends helps to overcome any uneasiness about it. The problem with the term 'Islamic feminism' lies in the tendency to (sometimes unwittingly) essentialise Islam - to see 'Islam' as a given religious paradigm. Outside observers as well as fundamentalist ideologues use it in this sense. Yet it is exactly the essentialisation of the paradigm that Islamic feminists have sought to deconstruct. They see inequality as a result of historical, intellectual, and political processes that reflected a certain distribution of power. The discriminatory effects of Islamic laws may be traced back to a certain male-dominated tradition of interpretation, but also to the modern practice of secular and theocratic national states.

When we look for the place of religion in Islamic feminism, we cannot find it in any single dominant role. Many Islamic feminist are motivated by Islamic values, but their approach to religion varies: they concentrate on the revealed foundation and its interpretation, on law and jurisprudence, on abstract religious thought, or on stateimposed legal provisions. What unites all Islamic feminist thinkers is that they are introducing an original perspective into the sphere of intellectual or social reforms that in some way have to do with religion, religious law, institutions, philosophy, modernity, etc. Hence, 'religion' in Islamic feminism means many different things.

The above reflections argue that Islamic feminism cannot be regarded as primarily religious if we are to avoid adopting an essentialised view of Islam. Rather, Islamic feminism works with the social reality of religious norms and discourses, be it in the hermeneutical practice of an ijtihadi and her or his critique of the received Islamic tradition, in the reformist's efforts to offer an answer to the ideologisation of religion, or in legal activism aimed at the practical realisation of equality. Islam and Islamic refer to what individual actors themselves invest in the term; not to a given paradigm. From this perspective, there should be as little in the way of preconceptions or unease 
around the concept of Islamic or islamic feminism (as Rhouni writes) as there is around that of 'Christian' or 'Jewish' feminism.

\section{References}

Abou-Bakr, O. 2015. 'Islamic Feminism and the Equivocation of Political Engagement.' Multitudes, Vol. 3, No. 60: 198-208.

Badran, M. 2005. 'Between Secular and Islamic Feminism/s. Reflections on the Middle East and Beyond.' Journal of Middle East Women's Studies. Vol. 1, No. 1: 6-28.

Badran, M. 2008. 'Engaging Islamic Feminism.' in Kynsilehto, A. (ed.). Islamic Feminism: Current Perspectives. Tampere Peace Research Institute, Occasional Paper No. 96.

Badran, M. 2009. Feminism in Islam: Secular and Religious Convergences. Oxford: Oneworld Press.

Badran, M. 2010. 'Re/placing Islamic Feminism.' Critique Internationale, Vol. 1, No. 46: 25-44.

Barlas, A. 2002. 'Believing Women' in Islam: Un-reading Patriarchal Interpretations of the Qur'an. Austin: University of Texas Press.

Barlas, A. 2015. 'Qur'anic Hermeneutics and Women's Liberation.' In Curtis, E. The Bloomsbury Reader on Islam in the West. New York: Bloomsbury.

Barlas, A. 2008. 'Engaging Islamic Feminism: Provincializing Feminism as a Master Narrative.' in Kynsilehto, A. (ed.). Islamic Feminism: Current Perspectives. Tampere Peace Research Institute, Occasional Paper No. 96.

Chabbi, J. 2016. Les Trois Piliers de I'islam: Lecture anthropologique du Coran. Paris: Seuil.

Cooke, M. 2000. 'Multiple Critique: Islamic Feminist Rhetorical Strategies.' Nepantla: Views from South, Vol 1, No. 1: 91-110.

Eddouada, S. 2008. 'Implementing Islamic Feminism: The Case of Moroccan Family Code Reform.' Pp. 37-46 in Kynsilehto, A. (ed.). Islamic Feminism: Current Perspectives. Tampere Peace Research Institute, Occasional Paper No. 96.

Göle, N. 1996. The Forbidden Modern: Civilization and Veiling. University of Michigan Press.

Hallaq, W. 1984. 'Was the Gate of ljtihad Closed?' International Journal of Middle East Studies, Vol. 16, No. 1: 3-41.

Hidayatullah, A. 2014. Feminist Edges of the Qur'an. Oxford: Oxford University Press.

Mir-Hosseini, Z. 2006. 'Muslim Women's Quest for Equality: Between Islamic Law and Feminism.' Critical Inquiry, Vol. 32, No. 4: 629-645.

Mir-Hosseini, Z. 2007. 'How the Door of ljtihad Was Opened and Closed: A Comparative Analysis of Recent Family Law Reforms in Iran and Morocco.' Washington \& Lee Law Review, Vol. 64, No. 4: 1499-1511.

Mir-Hosseini, Z. 2013. 'Justice, Equality and Muslim Family Laws: New Ideas, New Prospects.' Pp. 7-34 in Mir-Hosseini, Z., Vogt, K., Larsen, L., Moe, C. (eds.). Gender and Equality in Muslim Family Law. London: I. B. Tauris.

Mernissi, F. 1991. Women and Islam: An Historical and Theological Inquiry. Oxford: Blackwell.

Moghadam, V. 2008. Feminism, legal reform and women's empowerment in the Middle East and North Africa. International Science Journal Vol. 59/191 
Rhouni, R. 2010. Secular and Islamic Feminist Critiques in the Work of Fatima Mernissi. Leiden: Brill.

Sadeghi, F. 2010. 'Bypassing Islamism and Feminism: Women's Resistance and Rebellion in Post-revolutionary Iran.' Revue des mondes musulmans et de la Méditerranée, No. 128: 209-228.

Salime, Z. 2011. Between Feminism and Islam: Human Rights and Sharia Law in Morocco. Minneapolis: University of Minnesota Press.

Sonbol, A. el A. 2002. 'Rethinking Women and Islam.' Pp. 108-146 in Haddad, Y., Esposito J. L. (eds.). Daughters of Abraham: Feminist Thought in Judaism, Christianity, and Islam. University Press of Florida.

Soroush, A. 2008. The Expansion of Prophetic Experience. Essays on Historicity, Contingency and Plurality in Religion. Leiden: Brill.

Spahić-Šiljak, Z. 2017. 'The Confluence of Islamic Feminism and Peacebuilding: Lessons from Bosnia.' Samyukta: A Journal of Gender \& Culture, Vol. 17, No. 1: 165-181.

Steger, A. K. 2017. 'Islamic Feminism' in Lebanon: Portraying a Counter-discourse. Beirout: Heinrich Boell Stiftung.

Wadud, A. 2006. Inside the Gender Jihad: Women's Reform in Islam. Oxford: Oneworld. Wadud, A. 1999. Qur'an and Woman. Rereading the Sacred Text from a Woman's Perspective. New York: Oxford University Press.

(a) BY-NC Zora Hesová, 2019.

(a) BY-NC Institute of Sociology of the Czech Academy of Sciences, 2019.

Zora Hesová, PhD, is a researcher at the Institute of Philosophy of the Czech Academy of Sciences, and an assistant professor at Charles University, Prague. She graduated from the Free University Berlin and obtained her PhD in Islamic Philosophy from Sarajevo University. Her current research projects include: Islam in the Balkans; Islamic intellectual history; religion and populism in Central Europe. Contact email: zora.hesova@ff.cuni.cz. 